\title{
Investment In Top Architecture And Its Potential For The City
} BAUMANNOVÁ Milada ${ }^{1, a^{*}}$, ČESELSKÝ Jan ${ }^{2, ~ b}$, ŘEZÁČ Miloslav ${ }^{3, c}$

\author{
1, 2, 3VSB-TU Ostrava, FCE, Department of Architecture, L. Podéště 1875, Ostrava-Poruba, 70833, \\ Czech Republic
}

amilada.baumannova@vsb.cz, bjan.ceselsky@vsb.cz, 'miloslav.rezac@vsb.cz

Keywords: architecture, investment, brownfields, restructuring

\begin{abstract}
Over a long period city of Ostrava has contended with consequences of termination of vast, intensive, long term industrial activity of heavy industry. City area consists of $10 \%$ of brownfields and blackfields. These grounds are not, apart from a few exceptions, adequately integrated, from architectural and functional point of view, into the structure and image of the city. They are primary source of aesthetical and functional ,pollution“ and secondary source of air pollution in the form of dust from surfaces of forsaken sites, exposed slag heaps, tailings piles and disposal sites. Consequences of historical industrial heritage can be handled in a three different ways. There is a theoretical possibility to retain and revitalize all the historical industrial sites. More probable and more realistic, from economic point of view, is, however, to conserve and renew the most outstanding sites, the rest to pull down and reuse the vacated grounds in a new functional way. Finally, the radical solution consists of refusing industrial history of the city and removing all the industrial sites with an exception of small solitary industrial artefacts. When assessing efficiency of a new use of area or building impacted by former industrial activity it is necessary to check if the former or the latter are not contaminated which would represent a significant threat to ecosystems and environment. A level of cleansing of the area is dependent on the mode of functional utilization of the locality and it surroundings stipulated in a city master plan. The aim of the article as a comparison of a ,restart" of 2 European formerly important industrial cities with an approximately even number of inhabitants which dealt with redevelopment of extensive vacated, once industrial, areas in the city centre at around the same time frame; and an analysis of the benefits to the city brought by new investment. Ostrava located in the North East of the Czech Republic is compared to Bilbao located in the North East of Spain.
\end{abstract}

\section{Introduction}

Industrial revolution, whose bearers were important historical industrial cities, started the process of industrialization. During the industrialization process industrial production, which played a dominant role in the economy of each country and region, increased enormously. Industrialization brought important social and political changes together with urbanization. In general industrialization led to increase in standards of living but had negative effects as well: pollution of the environment or depletion of natural resources to name a couple.

Evolution of world industry of the 20th century is characterized by a process of deindustrialization which brings about decrease of employment in the production plants with low added value. This process is typical for developed economies and goes hand in hand with transfer of production to near shore and off shore destinations. Industrial cities that bloomed during the industrial age found themselves in a lengthy economic, ecologic, social and moral crisis. One of the possibilities to ensure economic recovery and growth was to prepare conditions to attract new investment which would improve the image of the city and generate new jobs.

The aim of the article is an analysis of restructuring progress of two significant European, former industrial, cities with an approximately even number of inhabitants, which are centres of metropolitan territories about the same size and which dealt with redevelopment of extensive vacated, once industrial, areas in the city centre at around the same time frame with emphasis put on assessment of the return on investment in the unique architecture and evaluation of its multiplier effect. 


\section{Restructuring of Ostrava City}

In the middle of 19th century city of Ostrava underwent a massive industrialization focused on mining, metallurgy and chemical industry. It became the most important strategic industrial centre in the Austro-Hungarian Empire and in Czechoslovakia respectively. Following the collapse of the communist regime in 1989 a market economy has been introduced and implemented resulting in deindustrialization of the economy. The old industrial sites that could not compete and did not comply with ecologic regulation were closed. According to the information available on the official website of the City of Ostrava 79 brownfields, occupying area of $19,04 \mathrm{~km}^{2}$ (8,9\% of the city), emerged in the city area over the 200 years history of industrial activity [1].

Nová Karolina (area of $32 \mathrm{ha}$ ) and Dolní Oblast Vítkovice (area of 150 ha) represent the two largest and, due to its proximity to the city centre, the most important brownfields of Ostrava.

\section{Restructuring of the Centre of Ostrava City - "Nová Karolina” project (design 2006)}

The industrialization of today`s Nová Karolina territory was initiated back in 1837 when pit Karolina, coking plant Karolina and steelworks Žofie were constructed. By 1985 all the buildings with the exception of 2 were pulled down. The remaining buildings have been protected as monuments of industrial architecture. A costly decontamination of polluted grounds situated in the area of a former pit and coking plant took place in the $90 \mathrm{~s}$ of the 20 th century. It was turned into a building ground (see Fig. 1) which bordered with the city centre, therefore being suitable to enlarge the city centre. The city council was aware of a historic opportunity to develop such an attractive territory, therefore an international urban planning and architectural competition was proclaimed in 1998. The outcome of the competition was not put into practice since there was no investor to finance such an enormous project. A new, this time development competition, was announced by the city council in 2005 .

The development project, Nová Karolina, became one of the biggest city development projects in the Czech Republic. The cost of the project which was divided into 4 phases is planned at 15 billion CZK. Nová Karolina is a unique project even by European standards because it envisages future integration with the transformed showground Černá louka and with redeveloped area of Dolní Oblast Vitkovice, the second most important brownfield. Altogether the project deals with an area of 200 ha in the central city location.

The project was started in 2008. The city council together with citizens had a high expectation of the project to revive the city centre, make it more attractive and publicize the city as a whole. The new buildings designed by the world-renowned architects such as Rem Koolhas or Eva Jiřičná were supposed to follow the realizations of famous architects of past Camillo Sitte and Erich Mendelsohn.

Building Forum Nová Karolina - multifunction centre of total area of $240000 \mathrm{~m}^{2}$. The architectural concept of the building has been designed in atelier OMA (Office for Metropolitan Architecture) of Rem Koolhas and his partners. The concept was based on the principle of exact geometric cubes of different sizes placed in the space freely crossing outside in and inside out united by large glass roof. During the further stages of the project the concept has been significantly changed without cooperation with OMA. As a result architectural quality of the building has been impacted.

Footbridge construction - it ensures an important and busy connection of Nová Karolina to railway and bus stations.

The design of a unique elegant subtle footbridge was created by the London office of the Czech architect Eva Jiřičná. Due to the high cost of the construction the concept has been replaced by a cheaper solution.

The other buildings such as Nová Karolina Park and apartment blocks do not bring the requested aesthetic value. The first stage of Nová Karolina has been completed by the ceremonial opening of the renewed historic building of Trojhalí. The project should continue in the 3 stages one following each other. 


\section{Restructuring of the Centre of Bilbao city - "Guggenheim Museum" project (design 1991)}

The city of Bilbao underwent an intensive industrialization during the $19^{\text {th }}$ century industrial revolution and it became an important centre of industry focused on metallurgy. In the $20^{\text {th }}$ century the old uneconomic and unecological heavy industry sites were gradually closed. The buildings of plants were pulled down and the brownfield areas in the city centre were turned into new development areas. The main goal of the local government was to make the city more attractive, as it had suffered from the crisis in the 80 s of the $20^{\text {th }}$ century due to its orientation towards heavy industry.

A public discussion on the construction and placement of a unique but costly project of Guggenheim museum in the style of deconstructivism designed by Frank Gehry in the city started in early 90s. After a one year of discussions the government of autonomous Basque Country decided not to rely on the central government but to finance the project with support of an association named Bilbao Metropoli-30. The association was constituted in 1991 by the City council of Bilbao, the Biscay and Basque Governments and diverse public and private organizations for the regeneration of Metropolitan Bilbao. The museum construction was part of 145 ha redevelopment project (Fig. 1).

The architectural competition on the design of the museum took place in 1991, the building itself was constructed between years 1993-1997 on the area of $32700 \mathrm{~m}^{2}$. Based on the available information the return on investment was achieved after 6 years of service. Moreover around 3800 jobs were created [2]. In 2010 the museum visited almost one million visitors of which $60 \%$ came from abroad [3].
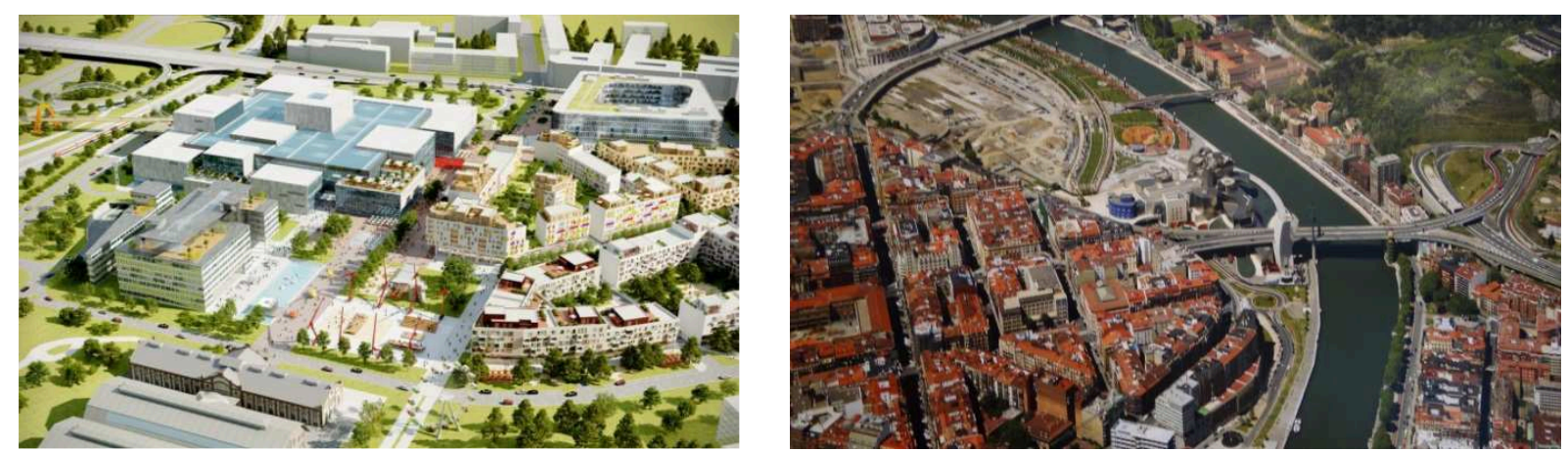

Fig. 1. Winning proposal of Nová Karolina Development project (Ostrava City); Area for new development activities, Guggenheim museum in the foreground (Bilbao City)

This effect has been called Guggenheim effect. The city tourism had increased. The bold approach of the Basque government brought a range of world renowned architects to the city. The brownfield areas are being gradually filled with modern buildings designed by famous architects from all over the world:

Euskalduna Palace (arch. F. Soriano a D. Palacios, r. 1999), Iberdrola Tower (arch. C. Pelli, r. 2008), University Library (R. Moneo, r. 2009), Basque University (arch. Alvaro Siza, r. 2010). Urbanistic conception of reconstruction of former industrial centre into elegant part of modern city is impressive: Campo Volantín waterfront, Atea towers (arch. A. Isozaki, r. 2009), zubi-zuri pedestrian bridge over Nervión river (arch. S. Calatrava, r. 1996). The symbol of the new city is also a subway network and its stations Fosterios (arch. Lord N. Foster, r. 1995). Last but not least to mention is La Sondika terminal (arch. S. Calatrava, 2000). As a part of a generous redevelopment of Bilbao city the public space has been rearranged based on the principles of architect Jan Gehl. The city has turned into the place for people where automobile traffic is limited, the transport is secured by subway and public transport, the static transport is rerouted to underground. The city parter has become attractive, appealing, safe, popular and pleasant place for meetings of locals as well as visitors. 


\section{Comparison of restructuring of Ostrava City and Bilbao City}

Flamboyant projects often arouse disputes within the professional as well as the non-professional public. This was the case of Guggenheim museum in Bilbao. However, the museum, one of the most striking and eccentric buildings of the past decade proved justifiability of progressive architecture. Successful restructuring of former Spanish industrial metropolis and substantial change to its image has been drawn by realization of ultramodern architectonic project. Since its opening in 1997 it has become the Mecca of modern architecture [4].

In 2006 when the winning project of Nová Karolina redevelopment was chosen, the museum in Bilbao had already been in service for 9 years. The Guggenheim effect became evident and the majority of buildings designed by world renowned architects were already completed. The model of Bilbao city has proven that the strategy of construction of architectural unique objects represents for former industrial cities the right path, and brings an important economic and social effect.

This model could have been an inspiration for Ostrava city. Based on the reaction of professional and lay public regarding the realization and operation of the first phase of the project of Nová Karolina, it is clear that Ostrava didn't take advantage of the opportunity to substantially change its image to restore the pride of Ostrava citizens to their broad public positively perceived city. The unique architecture would guarantee inflow of tourists which would contribute to the recovery of the city economy. In terms of accessibility, the situation of both cities is similar. Ostrava city is connected to a European highway system, Railway high speed corridors; it disposes of the airport with sufficient passenger capacity and efficient public transport system. The inflow of visitors would, similarly to Bilbao, lead to pressure on enlargement of public space areas and necessity to handle static and passenger car transport in the city centre, aestheticize the parter and surroundings which would help to the city.

\section{The multiplier effect of top architecture}

Cultural industries (creative industry) is not only one of the primary sources of innovation for other areas and an important driver of the economy as a whole, it is also, together with tourism (cultural tourism), is the fourth or fifth fastest growing sector in developed economies after the financial services, information technology, pharmaceutical industry and bioengineering [5]. According to estimates of the United Nations creative industries created in $2010,7 \%$ of global GDP with an annual increase of $10 \%$ [6]. Alone architecture (as part of the cultural infrastructure), no matter how good the quality is, no gain, and therefore, of course, nor any positive economic effect for the near neighbourhood, city or region guarantee. However, if combined with the architecture of the world famous "brand" = author and thoughtful marketing move, the total value of which exceeds the physical value of the building. An example might be the project of the Guggenheim Museum in Bilbao, the total economic benefits the museum in the period 1997-2003 amounted to $1,072,845,000$ euros, or roughly four times the cost of its creation and operation costs [7]. This situation is however conditioned by three fundamental aspects: tool = strategic plan of the City and the Region, product $=$ existence of architectural act value-added world-famous brand and place $=$ location with the greatest impact on the target group [8].

\section{Conclusion}

Bilbao city is experiencing a modern renaissance. Former Spanish centre of industry generously changed its uncomplimentary face. Brave decision of the town council paid off and the city became known to the expert and lay public as a world centre of modern architecture, architectural goal of world tourism a significant part of the cultural industry. The Guggenheim Museum in Bilbao exceeds its measure by a vast and dimensional complexity of everything that we have so far assumed that the architecture is aesthetically and technically possible.

Ostrava city still has the opportunity to inspire success of Bilbao. The city is considering a longterm implementation of significant cultural objects, such as a concert hall, library, gallery, which 
will extend its meaning beyond the city and region. It is possible to speak about the potential of the cultural cluster of Ostrava. Key to this will be the added value of Ostrava, without a doubt, courage city council prepare thoroughly architectural acts with analyses of the consequences for the city and region and courage to invest large sums of money to these architectural acts.

\section{References}

[1] Information on http://www.ostrava.cz/cs/o-meste/zivotni-prostredi/brownfields/brownfields

[2] Information on http://www.economist.com/news/special-report/21591708-if-you-build-it-willthey-come-bilbao-effect

[3] Information on http://www.tyden.cz/rubriky/domaci/13-

03_66500.html?showTab=diskutovane\#.U7vAQ_1_sZM

[4] Information on http://www.archiweb.cz/news.php?action=show\&id=4246\&type=2

[5] L. Ghilardi, Cultural Planning: A Sustainable Approach to Cultural Development, 2005. Presentation - CCP Meeting, Luxembourg, 06/2005.

[6] T. Raabová, Multiplikační efekty kulturních odvětví v české ekonomice, Study presented in the framework of the Project "Studie stavu, struktury, podmínek a financování umění v ČR" supported by the Ministry of Culture, Czech Republic, Praha, 2010.

[7] L. Kelner, Marketing a management muzeí a památek, Grada Publishing, Praha, 2005.

[8] Information on http://www.cbarchitektura.cz/2014/02/bilbao-efekt.html 